\title{
Tilgivelse: A tro, formidle og skape rom for det
}

\author{
Intervju med prest og trosopplaerer
}

\author{
Av Elisabet Kjetilstad, Irlin Bråten \\ og Gunnfrid Ljones Øierud \\ Elisabet Kjetilstad, fengselsprest, e-post: ek477@kirken.no \\ Irlin Bråten, trosopplaringsleder, e-post: ib776@kirken.no \\ Gunnfrid Ljones Øierud, redaktør i Prismet, e-post: gunnfrid.l.oierud@iko.no
}

Tilgivelse er et av de helt sentrale ordene $i$ kristendommen. I Den norske kirkes plan for trosopplaring heter det at barn og unge skal kunne "forstå seg selv og tilvarelsen $i$ lys av relasjonen til Gud, seg selv, andre mennesker og i forhold til resten av skaperverket» (Gud gir - vi deler, s. 14). Tilgivelse kan beskrives som noe som utruster barn og unge til a mote livets mange utfordringer og relasjoner med realisme og nåde. Men hvordan blir dette kommunisert for de unge som deltar i Den norske kirkes trosopplaring? Hvilken forstålse av tilgivelse moter barn og unge? Larer de å tro på tilgivelsens betydning i eget liv? Prismet har invitert en prest og en trosopplaringsleder til å reflektere over tilgivelse og om trosopplaering med tilgivelse som tema, ut fra sine perspektiv. De to har tidligere jobbet side om side $i$ samme menighet, men nå har presten byttet jobb til fengselsprest og har dermed fätt noen nye erfaringer og refleksjoner om temaet.

Elisabet Kjetilstad har jobbet som prest siden 2006, derav 10 år i Høybråten, Fossum og Stovner menighet. Nå er hun fengselsprest i Bredtveit fengsel. Irlin Bråten er utdannet cand. theol og har jobbet som trosopplæringsleder i Høybråten, Fossum og Stovner menighet siden 2016. Elisabet har også bak seg opphold ved et freds- og forsoningssenter i Irland, og har interesse for en organisasjon som heter «The Forgiveness Project» (https://www.theforgivenessproject.com/). Irlin var parallelt med studiene med i samtaletjeneste i Oslo kretsfengsel, et tilbud i regi av Storsalen menighet.

\section{Tilgivelse SOM TEMA}

Prismet: Irlin og Elisabet, kan dere fortelle litt om deres erfaringer fra trosopplaring og kirkelig praksis, undervising og forkynnelse om tilgivelse blant barn og unge? Er det for eksempel noen bestemte trosopplaringstiltak som sarlig vektlegger tilgivelse?

Irlin: I menigheten hvor jeg jobber, har vi ikke noen spesifikke trosopplæringstiltak med overskriften «tilgivelse». Det er heller slik at tilgivelse som tema er integrert inn i de ulike trosopplæringstiltakene. Vi møter tilgivelse som tema i 
Bibelfortellingene, i undervisningen om Jesus, i høytidene og i menneskelige erfaringer som barn og unge inviteres med inn $i$.

Elisabet: Mange av trosopplæringstiltakene knyttes også opp mot gudstjenester, hvor vi i bønnen Fader Vår ber om at Gud må «tilgi oss vår skyld, slik også vi tilgir våre skyldnere». De som følger kirkas trosopplæringstiltak gjennom barndommen, vil etter hvert ha møtt denne bønnen og dette ordet «tilgivelse» mange ganger, både i kirka og andre sammenhenger. Det er en veldig fin side ved at tilgivelsen naturlig er bakt inn i de ulike trosopplæringstiltakene og at trosopplæringen knyttes opp til gudstjenester. Samtidig kan dette innebære en fare for at tilgivelse som tema ikke får stå for seg selv, men alltid «følger med» og «drukner» i mange andre tema som også følger med i for eksempel fortellingene om Jesus?

Irlin: Jeg skjønner hva du mener, og som trosopplæringsleder er jeg oppmerksom på dette. Og selv om tilgivelse som tema følger med hele veien, får tilgivelse ekstra fokus i forbindelse med undervisningen og bokutdelingen til 4-åringene hvor vi snakker om Sakkeus.

\section{VEKTLEGGING}

Prismet: Hva vil dere si vektlegges ved tilgivelse i trosopplaringen?

Elisabet: Jeg opplever at kirka knytter fenomenet «tilgivelse» sammen med «det dobbelte kjærlighetsbudet»: At tilgivelse handler om kjærlighet både til seg selv og nesten. Det er to eksistensielle tema knyttet sammen og ofte ledet ut i setninger som: «Du er elsket. Du er tilgitt»...

Irlin: ... og i trosopplæringen følger typisk setningen «du er god nok». Det blir ofte sagt, og det trengs at kirka sier det i en tid hvor barn og unge opplever krav fra mange kanter. Kirka vil formidle at vi som er elsket og tilgitt, skal være rause både med oss selv og med hverandre. Den enkelte av oss har verdi, selv om vi ikke alltid strekker til eller gjør alt rett. Ingen er perfekte, og når Gud hele tiden gir oss nye sjanser, er også vi kallet til å gi hverandre nye sjanser. Tilgi oss selv og tilgi hverandre. I trosopplæringstiltaket for 4-åringene får barna høre om Sakkeus som ikke nådde opp i folks øyne og som var for lav til å kunne få øye på Jesus, men som likevel fikk sitte til bords med Jesus.

Elisabet: Fortellingen om Sakkeus er også viktig i konfirmasjonstiden. Da kan fokuset fra trosopplæringstiltaket for 4-åringene utvikles videre. Både som konfirmant- og fengselsprest leser jeg gjerne bibelfortellingene ved hjelp av kontekstuell metodikk, hvor målet er å bygge bro mellom bibelteksten og leserens kontekst og liv. Jeg husker mange gode samtaler om hvordan Jesus ser Sakkeus som et menneske med et bankende hjerte. Hvordan Jesus ser hans ensomhet, lengsel, skam og anger. Sammen med konfirmantene eller de innsatte oppdager jeg på nytt og på nytt hvordan Jesus både bekreftet og utfordret Sakkeus, og ble hos ham også da Sakkeus erkjente at hans rikdom kom fra utbytting og utpressing av 
andre. Istedenfor å gå bort fra Sakkeus, sa Jesus: «I dag har frelse kommet til dette hus ... For Menneskesønnen er kommet for å lete etter de bortkomne og berge dem». I møte med Sakkeus praktiserer Jesus kjærlighet, og selv om Jesus ikke sier ordet «tilgivelse» $i$ denne fortellingen, er vi invitert inn i tematikken. Kan vi bli hos hverandre når urett har skjedd? Tør vi innrømme for oss selv og hverandre det gale vi har gjort, og kan vi tilgi og tilgis? Konfirmantene var engasjerte. I fengselet hvor jeg nå jobber, kommer spørsmål som disse enda tettere på, mange av de innsatte kjenner seg som Sakkeus idet Jesus sender sitt første blikk i hans retning. Hva vil skje? Er jeg elsket? Er jeg ... tilgitt? Kan jeg ... tilgi meg selv?

Irlin: Sakkeus blir ikke forlatt, men făr sin gjenopprettelse i relasjonen, i fellesskapet med Gud og mennesker. Det får meg til å tenke på et kurs jeg og noen kollegaer deltok på og som vi ønsker å bruke inn i menighetens trosopplæring, nemlig et metodisk program som formidler tro og bibeltekster og som på norsk går under navnet «gudsrikeleiken» (https://godlyplay.no). Her ble nattverdsfortellingen stilt sammen med fortellingen om sauen som går seg vill. Først fortelles de to fortellingene hver for seg. Vi inviteres først inn i nattverdsfortellingen, deretter møter vi den villfarne sauen som blir funnet. I siste scene stilles de to fortellingene sammen, ved at Jesus tar med seg sauen til nattverdsbordet. Ved å ta i bruk denne fortellingen kan vi i trosopplæringen formidle at selv om vi går oss vill, er vi alltid inviterte tilbake til fellesskapet. Det er et uttrykk for tilgivelse.

\section{ERFARINGER}

Prismet: Har dere erfaringer fra kirkelig undervisningspraksis om tilgivelse som dere vurderer som ikke så gode?

Irlin: Jeg har ikke noen spesifikke erfaringer, selv om det selvsagt har hendt at jeg ikke følte vi landa helt. De gangene tror jeg det ikke nødvendigvis har handla om opplegget, men heller om timing og tid. At vi har satt $i$ gang prosesser hos deltakerne som vi ikke hadde forutsetninger for å ta imot ...

Elisabet: Ja, det er sant. I menighetssammenheng er det ofte store grupper med mennesker som alle har sine erfaringer med temaet tilgivelse. Rører vi opp mange tanker og følelser uten å ha tanke for hvordan vi vil romme dette, kan det bli en påkjenning for deltakerne.

En annen planleggingsmessig tabbe kan være å legge opp til et altfor tettpakket program, hvor vi hopper fra det ene sterke temaet til det andre, uten å gi tid til deltakerne til både å ta inn, ta del og plassere det som blir tematisert. Det kan være gleden, javisst, men også det alvorlige, det skumle, det ubehagelige, utfordrende ... Har vi i planleggingen tatt høyde for å være sammen med deltakerne i dette, for eksempel ved å ta det inn i en rituell handling som lystenning, eller ved å invitere til samtale i etterkant? 


\section{Tilgivelse i fengsel Og Kirke}

Prismet: Elisabet, kan du fortelle litt om hvordan tilgivelse kommer frem som tema $i$ din tjeneste som fengselsprest, sammenlignet med erfaringene dine som menighetsprest?

Elisabet: Da jeg jobbet som menighetsprest, snakket jeg ofte mer systematisk og overordnet rundt tilgivelse, enn jeg giør i fengselet. Tilgivelse var tema i prekener og ulike pedagogiske opplegg for barn og unge. Selv om jeg også i fengselet preker og deler tanker om tilgivelse både i gudstjenester og samtale-grupper, vil jeg si at tilgivelse som tema først oppleves som særlig viktig i det fortrolige samtalerommet. Der kan spørsmålet om tilgivelse knyttes nærmere sammen med ens eget liv, og tre frem som et eksistensielt tema for den enkelte. Kanskje kan hun våge spørsmålet: Hva betyr tilgivelse for meg, i denne situasjonen og relasjonen som jeg nå er i?

Prismet: En større veklegging av tilgivelse som personlige prosesser, altså?

Elisabet: Ja, det vil jeg si. Som fengselsprest kan jeg inviteres inn i samtaler hvor vi kan bli kjent med kompleksiteten rundt hva tilgivelse kan bety og innebære i den enkelte sitt liv, samt hva tilgivelse ikke er. Jeg husker samtaler som handler om å plassere skyld og ansvar, og spørsmålet om det alltid er rett å tilgi? Mange opplever det frigjørende å rydde i begrepene «tilgivelse» og «forsoning». Er «tilgivelse» og «forsoning» det samme? Og må det tilgivelse til for å oppnå forsoning?

I samtaler med kvinner i fengsel oppdager jeg ofte at ikke bare tilgivelse er et sammensatt tema, men at livet selv og årsaks-sammenhengene for hvorfor livet ble som det ble, er komplekse. Jeg opplever at kvinner i fengsel ofte både er offer for andres ugjerninger og selv utøver av skadelige handlinger mot andre. Hvem skal tilgi hvem? Og når har hun sonet lenge nok, når kan hun tilgi seg selv? Kan Gud tilgi det som et menneske ikke makter å tilgi?

Prismet: Hvordan ser du på den kirkelige undervisningen og praksisen med tilgivelse når du nå har erfaring som fengselsprest - ser du nye styrker/svakheter? Eller har du nye forslag til undervisning og forkynnelse om tilgivelse i kirkelig sammenheng?

Elisabet: Jeg tror generelt at kirkas trosopplæring har mye å hente på å utvikle samspillet mellom undervisning i de større gruppene og samtalene i de mindre rommene, samt å bygge bro mellom Bibelfortellingene, eget liv og samfunn. Jeg håper kirka kan bli tydeligere på å invitere konfirmanter og konfirmantledere til enkelt-samtaler om livets eksistensielle tema som for eksempel tilgivelse. Det er fint og viktig å bli kjent med Jesus sine ord om tilgivelse, og som kirke i det livsynsåpne samfunn er det også spennende å lede en oppdagelse av tilgivelsens plass $i$ andre tros- og livssyn, men i forlengelsen av denne undervisningen mener jeg at barn og unge bør inviteres til den personlige refleksjonen: Må jeg tilgi? Vil jeg tilgi? Er det rett? Og i tilfelle ja: hvordan skal jeg gjøre det? For en ting er å ville tilgi (om man vil det), men hvordan gjør man det? Er det noen praktiske råd? 
Hvordan vil kirka svare på det i trosopplæringen, når konfirmanten helt på alvor spør? Her finnes ikke et standard svar som kirkens undervisere kan pugge. Men her bør finnes omsorg og tid til å følge den unge i sin søken.

Til spørsmålet du stiller om forslag til undervisning for å ta opp tema tilgivelse, tenker jeg på erfaringer ulike organisasjoner som arbeider med freds- og forsoningsarbeid, har gjort med å lytte til levende menneskers fortellinger om hvordan de har opplevd tilgivelse i eget liv.

Gjennom menneskers fortellinger om erfaringer av tilgivelse i eget liv, kan vi åpne språket om tilgivelse for barn og unge. Vel vitende om at enkeltmenneskers erfaringer av tilgivelse ikke kan gjøres til norm for alle, kan de like fullt være inspirerende erfaringer inn i egen prosess. 